\title{
The Life Cycle of Diamondiferous Cratons - A Leitmotif with Infinite Regional Variations
}

\author{
Herwart H. Helmstaedt \\ Queen's University, Kingston ON, Canada, helmstaedt@queensu.ca
}

\section{Introduction}

The evolution of most primary diamond deposits is multi-stage and intricately linked to the tectonic histories of their host cratons and their lithospheric and sublithospheric underpinnings. Yet the integration of the surface geological record of diamondiferous cratons with the complexities observed within the diamond and xenolith populations of their primary igneous hosts (kimberlites, lamproites, etc.) remains a major challenge for both diamond explorers and tectonicians interested in craton formation. A comparison of primary diamond deposits on different cratons shows that whilst processes leading to the formation of such deposits have operated worldwide, the timing of individual diamondforming events and transport to the surface are craton specific. The recurring theme emerging from such comparisons involves five broad stages, referred to below as life cycle of diamondiferous cratons (Fig. 1). For an economic primary diamond deposit to form and survive to be mineable, the balance between diamond-friendly and diamond-unfriendly events during all stages of this cycle should be in favor of diamond survival. However, judging from the relatively small number of "high-grade" primary diamond mines, this was not the rule. Comparative step-wise craton analyses, integrating detailed geological evolution and geophysical settings with studies of the upper mantle sample from many deposits, bring out similarities and differences and assist in better evaluating the effects of terrane accretion, regional "granite blooms", rifting and plume events, etc. on the diamond potential of the cratons. This helps to establish more realistic diamond deposit models for area selection and provides important feedback for tectonic models of craton evolution.

\begin{tabular}{|c|c|c|}
\hline Stage 1 & $\begin{array}{l}\text { Earliest subcontinental lithosphere development with depleted roots and } \\
\text { harzburgitic P-type diamonds. Proto-continental nuclei. }\end{array}$ & $>3 \mathrm{Ga}$ \\
\hline Stage 2 & $\begin{array}{l}\text { Amalgamation of early nuclei and formation of first E-type diamonds. } \\
\text { First detrital diamonds appear in sedimentary record and primary igneous } \\
\text { rocks. Early roots must survive accretion of Neoarchean greenstone terrains, } \\
\text { various "granite blooms" and other diamond-unfriendly events. } \\
\text { Cratonization, greatest extent of Archean cratons. }\end{array}$ & $\begin{array}{r}\sim 3 \mathrm{Ga} \\
\sim 2.5 \mathrm{Ga}\end{array}$ \\
\hline Stage 3 & $\begin{array}{l}\text { Post-Archean break-up of Archean cratons, fragments become involved in } \\
\text { Proterozoic (and Phanerozoic) orogenic events and supercontinent cycles. } \\
\text { Archean craton roots are affected again by various mantle root-friendly or } \\
\text { unfriendly tectonic and magmatic events, either diminishing diamond content } \\
\text { of lithospheric source rocks or enhancing it by the addition of Proterozoic E- } \\
\text { type or, more rarely, by lherzolitic P-type diamonds. }\end{array}$ & $<2.5 \mathrm{Ga}$ \\
\hline Stage 4 & $\begin{array}{l}\text { Archean cratons may be intruded by one or more generations of kimberlites } \\
\text { or lamproites. Such events may be accompanied or preceded by metasomatic } \\
\text { alterations within or below the diamondiferous lithospheric roots. They may } \\
\text { also be preceded by growth of late-stage amber or fibrous diamonds (type lb). } \\
\text { Sub-lithospheric diamonds may be picked up by kimberlites at this stage. }\end{array}$ & $\begin{array}{l}\text { kimberlite } \\
\text { or } \\
\text { lamproite } \\
\text { emplacement }\end{array}$ \\
\hline Stage 5 & $\begin{array}{l}\text { Includes all geological factors controlling the preservation of diamondiferous } \\
\text { kimberlites or lamproites and the dispersal of indicator minerals. }\end{array}$ & $\begin{array}{c}\text { Post- } \\
\text { emplacement }\end{array}$ \\
\hline
\end{tabular}

Figure 1: Generic life cycle of a diamondiferous craton. 


\section{Discussion of Stages:}

Stage 1 involves the formation of the harzburgitic P-type diamond paragenesis, yielding the bulk of the diamond budget in many mines worldwide, but present in all econonomic kimberlites and lamproites, even though recognizable in some of the latter only as remants included in diamond (e.g. Argyle, Ellendale, Bunder). Where dated, it has consistently yielded >3 Ga ages (Gurney et al. 2010), which together with the worldwide association of P-type diamond deposits with > 3.0 Ga protocratons gave rise to the model that such protocratons were coupled to Mesoarchean roots prior to 3 Ga (e.g. Helmstaedt et al. 2010). Nevertheless, the significance of ancient diamond inclusion ages remains controversial, as on the Slave craton, where ca. 3.3 to $3.5 \mathrm{Ga}$ Re-Os isochron ages of sulfide inclusions in Panda and Diavik diamonds (e.g. Westerlund et al. 2006; Aulbach, 2009) were reinterpreted as mixing lines, compatible with Slave subcontinental lithospheric mantle (SCLM) formation at ca. 2.75 Ga (Heaman and Pearson 2010). However, models of craton construction based on these younger SCLM formation ages (e.g. Snyder et al. 2017) are incompatible with the ever increasing evidence for much earlier crust-mantle coupling on most diamondiferous cratons.

Stage 2 begins with the interactions between the proto-continental nuclei, involving various amalgamation and break-up events, and ending with cratonization at the end of the Archean. For the harzburgitic roots, this stage is the beginning of a long survival story, and histories of individual protocratonic nuclei diverge on different cratons and different regions of individual cratons. The oldest E-type diamond-forming events fall into this stage (Kaapvaal, Siberia) and are related to ca. 3.0 to 2.5 Ga accretion of Paleoarchean continental nuclei, each underpinned by a potentially P-type diamond bearing lithospheric root, into composite Archean cratons. Interactions between the continental nuclei involved subduction of intervening seafloor, partial melting of hydrated oceanic crust, and widespread formation of tonalite. The geological surface record shows accretion of up to several ages of greenstone sequences, turbidite basins, regional metamorphism, and various granitic intrusive events, some of which form regionally extensive "granite blooms". The formation of local rift basins may precede or accompany cratonization. On the Kaapvaal craton, lithosphere was thick enough for primary diamond deposits to be emplaced and recycled into ca. 2.9 Ga Witwatersrand deposits (e.g. Smart et al., 2016). On the Slave craton, the oldest cover sequence on the Mesoproterozoic Central Slave superterrane is slightly younger (ca. 2.8 Ga), but it has also yielded detrital diamonds (Jackson, 1997), hinting at the existence of an earlier Slave root. Early roots survived best where the older nuclei remained in the footwall during Neoarchean terrane accretion and greenstone belt emplacement (e.g. the eastern part of the Central Slave superterrane was overridden by the Contwoyto terrane; the southern part of the Zimbabwe raton was overthrust by the Northern Marginal Zone of the Limpopo belt). Major "granite blooms" have occurred on most cratons prior to cratonization. Although they had profound effects on crustal differentiation, they generally did not diminish the diamond potential in the lithospheric roots.

Stage 3: Archean cratons reached their greatest extents prior to Proterozoic break-up. After break-up, the tectonic settings of the kimberlitic and lamproitic deposits diverged significantly. Survival of roots depends on size of Archean craton fragments. Future sites of diamondiferous kimberlite remained well within the early Archean nuclei of their respective cratons, while passive rifting occurred at craton margins, whereas those of lamproitic deposits are located near the rifted margins of their respective cratons. Proterozoic convergent tectonism locally underplated eclogites from the craton margin (e.g. Slave craton kimberlites). Eclogites were also added to pre-exsiting P-type roots under lamproites by an as yet unknown mechanism (e.g. Argyle). Plumes impacting on diamondiferous cratons have a detrimental effect on the diamond potential.

Stage 4: This stage involves the analysis of the geotectonic and structural settings of the country rocks from the craton to local scales at the time of and leading up to kimberlite or lamproite eruption.The question whether plumes have an important role in triggering kimberlite and lamproite magmatism has been debated at length in the literature (e.g. Helmstaedt and Gurney 1997; Jelsma et al. 2009), but from detailed examinations of the structural setting of many kimberlites and lamproites, it is unlikely that their emplacement was directly triggered by plumes. For example, since the latest Precambrian at least 
six generations of kimberlites on the Slave craton were intruded while the craton was essentially near sea level. Both of the two most recent plumes known to have impacted the northern margin of the craton, are of Mesoproterozoic (Mackenzie plume, ca. $1270 \mathrm{Ma}$ ) and Neoproterozoic (Franklin plume, ca. 720 $\mathrm{Ma}$ ), the latter predating the oldest kimberlites by at least $100 \mathrm{~m} . \mathrm{y}$. On the other hand, a strong case has been made recently for the 75 to 45 Ma Lac de Gras kimberlites, that low-angle subduction along the western continental margin of North America is implicated in having provided fluids for late fibrous diamond formation and triggering of the kimberlite magmatism (Weiss et al. 2015; Currie and Beaumont 2011). However, plumes may have played a role in having metasomatized and fertilized the mantle at some time prior to the kimberlite magmatism. Detailed tectonic analyses in combination with studies of the upper mantle sample are necessary to examine this possibility.

Stage 5: Of crucial importance for a successful diamond exploration program is the post-emplacement history of kimberlites and lamproites. Exploration geologists must identify what geological factors were responsible for the preservation of the diamondiferous host rocks and what processes controlled the dispersal of the indicator minerals.

\section{References}

Aulbach, S., Stachel, T., Creaser, R.A., Heaman, L.M., Shirey, S.B., Muehlenbachs, K., Eichenberg, D., Harris, J.W. (2009) Sulphide survival and diamond genesis during formation and evolution of Archaean subcontinental lithosphere: A comparison between the Slave and Kaapvaal cratons. Lithos: $112,747-757$.

Currie, C.A., and Beaumont, C. (2011) Are diamond-bearing Cretaceous kimberlites related to lowangle subduction beneath western North America? Earth and Planetary Science Letters: 303, 59-70.

Gurney, J.J., Helmstaedt, H.H., Richardson, S.H., Shirey, S.B. (2010) Diamonds through Time. Economic Geology 105: 689-712.

Heaman, L. M., and Pearson, D. G. (2010) Nature and evolution of the Slave Province subcontinental lithospheric mantle. Canadian Journal of Earth Sciences: 47, 369-388.

Helmstaedt, H.H., Gurney, J.J. Richardson, S.H. (2010) Ages of cratonic diamond and lithosphere evolution: constraints on Precambrian tectonics and diamond exploration. The Canadian Mineralogist: 48, 1385-1408.

Helmstaedt, H. H. and Gurney, J. J. (1997) Geodynamic controls of kimberlites - What are the roles of hotspot and plate tectonics? Russian Geology and Geophysics: 38, 492-508.

Jackson, V.A, (1997) Preliminary geology of the Tree River area with descriptive notes, parts of NTS 86 P/1, 2 and 8: Geology Division, Department of Indian Affairs and Northern Development, Yellowknife, N.W.T., EGS Open file 1997-14.

Jelsma, H., Barnett, W., Richards, S., Lister, G. (2009) Tectonic setting of kimberlites. Lithos: 112S, 155-165.

Smart, K.A., Tappe, S., Stern, R.A., Webb, S.J., and Ashwal, L.D. (2016) Early Archean tectonics and mantle redox recorded in Wiwatersrand diamonds. Nature Geoscience: 9, 255-259.

Snyder, D.B., Humphreys, E., Pearson, D.G. (2017) Construction and destruction of some North American cratons. Tectonophysics: 694, 464-485.

Weiss, Y., McNeill, J., Pearson, D.G., Nowell, G.M., Chris J. Ottley., C.J. (2015) Highly saline fluids from a subducting slab as the source for fluid-rich diamonds. Nature: 524, 339-342 